\title{
MICROCLIMATE IN THE VERTICAL PROFILE OF WHEAT, RAPE AND MAIZE CANOPIES
}

\author{
Z. Krédl, T. Středa, R. Pokorný, M. Kmoch, J. Brotan
}

Received: March 17, 2011

\begin{abstract}
KRÉDL, Z., STŘEDA, T., POKORNÝ, R., KMOCH, M., BROTAN, J.,: Microclimate in the vertical profile of wheat, rape and maize canopies. Acta univ. agric. et silvic. Mendel. Brun., 2012, LX, No. 1, pp. 79-90

The differences of air temperature and relative air humidity in wheat, rape and maize canopies at three heights (ground level, effective canopy height and 2 meters above the soil surface), and their comparison with the temperature values of the nearest standard climatological station at the height of 2 meters were studied. The microclimatic data were obtained at the field trial station of the Mendel University in Brno in the Žabčice municipality (South Moravia) in the canopies of winter wheat, winter rape and maize and from the standard climatological station located immediately next to the canopies. It was found, that wheat, rape and maize canopies microclimate differed significantly from those of their surrounding environments. The temperature was usually lower in the ground level and effective height in the wheat and rape stands, air humidity was usually higher in these crops. On the other hand, maize canopies had diverse air temperature values during the studied period.
\end{abstract}

canopies microclimate, wheat, rape, maize, air temperature, air humidity

A significant amount of heat and water vapor enters the atmosphere as a result of the process of substance and energy exchange between the active surface and the lowest layers of atmosphere. As a result, a change of air temperature and humidity inside a canopy and immediately above it occurs. This way, every plant community creates its own microclimate and the climatic status of a canopy can be significantly influenced (Geiger, 1965). A canopy's microclimate plays a key role in the ecosystem processes, however, the predictive understanding of the vertical and horizontal variability in the heterogeneous landscape is missing to a high extend in spite of the fact that it has been observed that organisms, species and communities have diverse reactions to hourly, daily, seasonal and long period temperatures (Vanwalleghem \& Meentemeyer, 2009). The vertical variability is particularly complex because the combination of physiographic (e.g. altitude) and ecological (e.g. vegetation structure) factors impacts energy and humidity fluxes (Chen et al., 1999). The correlation between microclimate measuring at climatological stations and canopies microclimate measuring strongly depends on the canopy structure as well as on the height at which the measurement sensors are positioned (Chelle et al., 2009). Moreover, the temperature and humidity are a key variables on which epidemiologic processes such as infection, latency, lesions growth and sporulation of pathogens are depended upon (Chungu et al., 2001; Henze et al., 2007; Lovell et al., 2004). Epidemiological models of pathogens and pests occurrence prediction are usually based on measurements carried out by climatological stations - the values of air temperature and humidity, precipitation, wind speed etc. are mainly used. Nevertheless, Hallaire et al. (1969) presented that these climatic parameters were not optimal for creating these prognostic models and that it was more convenient to measure the meteorological parameters directly inside the canopy for a better understanding of the plant- pathogen- microclimate interactions

The aim of this work was to evaluate and describe the microclimatic characteristics of wheat, rape and maize canopies in relation to time, vertical variability of canopies and a standard climatological station by means of the linear regression analysis. 
An equally important objective was to display the air temperature and relative humidity values by isotherm and isolines of humidity values.

\section{MATERIALS AND METHODS}

The microclimatic data were obtained at the field trial station of the Mendel University in Brno in the Žabčice municipality in the canopies of winter wheat (Triticum aestivum L.), winter rape (Brassica napus L. ssp. napus) and maize (Zea mays L.) and from the standard climatological station located approximately 60 meters of the canopies (GPS Loc: $49^{\circ} 1$ '18.658"N, 16³6'56.003"E). Wheat was represented by the Sultan variety, rape by the Petrol variety, and maize by the NK Thermo hybrid. The experimental area is situated in the Svratka river flood plain at the average altitude of 184 above the sea level. According to the agro climatic classification (Kurpelová et al., 1975), the locality belongs to the warm macro area, predominantly warm area, predominantly dry sub area, region with rather mild winters. Viewed from the agricultural categorization, it is a maize production area. The standard annual temperature during 1961-1990 was $9.2{ }^{\circ} \mathrm{C}$, the annual precipitation standard was $483 \mathrm{~mm}$. The mean temperature was $15.6^{\circ} \mathrm{C}$ with the minimum $-0.1^{\circ} \mathrm{C}$ and maximum $33.5^{\circ} \mathrm{C}$ during measured period (7. 4.-11. 7. 2010). The mean air humidity was $72 \%$ with the minimum $23 \%$ and maximum $100 \%$

Data recording for each crop was carried out by means of a mobile meteo station equipped by digital temperature sensors (Dallas semiconductor, DS18B20 type) and air humidity sensors (analog sensor Honeywell HIH 4000) placed in the shade. The recorders were positioned at three levels (on the ground, at the effective height and at 2 meters above the ground) in order to cover the whole vertical profile. Sensors positioned at the effective height were moved up as the crop was growing. The effective canopy height is the height corresponding to approximately $70 \%$ of the actual canopy height. This part of the vegetation is important from the viewpoint of pathogen and animal pests' occurrence. The data recording at the standard climatological station was carried out by means of electronic recorders of air temperature and humidity HOBO (producer Onset Computer, USA) placed in the shade. Before the measurement of air temperature and air relative humidity in the canopies took place, the sensors were compared to the measurements by Vaisala HUMICAP HMP 35 for several weeks. In the case of Vaisala HUMICAP HMP 35 measurements, a deviation was found only for the relative air humidity $-2 \%$. The values of air temperature and humidity were continuously recorded at 15 minute - intervals during the whole vegetation season. The values of the meteorological parameters taken by the recorders were entered into a logger and downloaded by a self-service program into a portable computer. The basic representative data were selected and then evaluated at the time between wheat canopy closure (April 7th) and the harvest (July 11th, 2010). For statistical processing, the data were adjusted into hourly unit intervals by arithmetic average and for the purpose of this paper, the data were evaluated by the linear regression analysis used for canopy variable impact analysis in dependence on the surrounding environment's (ambient) temperature and humidity. Furthermore, values from the above the ground vertical profiles were evaluated by the method of triangulation with linear interpolation and graphically displayed in the form of isotherms and humidity isolines (isohumids) by the Surfer ver. 8.03 (Golden Software, Inc.) program.

\section{RESULTS AND DISCUSSION}

The air temperature and relative air humidity values inside and above the canopies were compared to the values of air temperature and relative humidity at the height of 2 meters above the grass canopy from the closest standard climatological station located immediately next to the wheat and rape canopies. By means of the regression analysis, the regression equations for estimation of the dependent variable (canopy temperature) for temperatures $5,10,15,20,25$ and $30{ }^{\circ} \mathrm{C}$ were obtained and at the same time, regression equations for estimation of canopy humidity for humidity values of $30,40,50,60,70,80,90$, and $100 \%$ were attained. The regression equations record the differences between the standard environment (temperature and humidity above the grass canopy

I: Monitored air temperatures above grass canopy $\left({ }^{\circ} \mathrm{C}\right)$ in comparison to wheat canopy when using regression analysis

\begin{tabular}{cccc}
\hline Grass $\mathbf{- 2} \mathbf{m}$ & Wheat - ground & Wheat - effective height & Wheat - 2 m \\
\hline 5 & 6.6 & 4.7 & 4.9 \\
10 & 10.1 & 9.5 & 9.9 \\
15 & 13.6 & 14.2 & 14.9 \\
20 & 17.1 & 23.7 & 19.9 \\
25 & 20.5 & 28.5 & 24.9 \\
30 & 24.0 & $\mathrm{R}^{2}=0.943$ & 30.0 \\
\hline Letermination coefficient & $\mathrm{R}^{2}=0.930$ & $\mathrm{y}=0.9503 \mathrm{x}-0.0486$ & $\mathrm{R}^{2}=0.979$ \\
Linear regression & $\mathrm{y}=0.6954 \mathrm{x}+3.1567$ & & $\mathrm{y}=1.004 \mathrm{x}-0.1478$ \\
\hline
\end{tabular}


II: Monitored air temperatures above grass canopy $\left({ }^{\circ} \mathrm{C}\right)$ in comparison to rape canopy when using regression analysis

\begin{tabular}{cccc}
\hline Grass $\mathbf{- 2 ~ \mathbf { ~ }}$ & Rape - ground & Rape - effective height & Rape - 2 m \\
5 & 6.0 & 4.2 & 4.6 \\
10 & 10.1 & 9.5 & 9.8 \\
15 & 14.2 & 14.8 & 15.0 \\
20 & 18.4 & 20.1 & 20.2 \\
25 & 22.5 & 25.5 & 25.4 \\
30 & 26.6 & 30.6 & 30.6 \\
\hline Determination coefficient & $\mathrm{R}^{2}=0.946$ & $\mathrm{R}^{2}=0.924$ & $\mathrm{R}^{2}=0.974$ \\
Linear regression & $\mathrm{y}=0.8274 \mathrm{x}+1.8145$ & $\mathrm{y}=1.0615 \mathrm{x}-1,0914$ & $\mathrm{y}=1.0391 \mathrm{x}-0.5595$ \\
\hline
\end{tabular}

III: Monitored air temperatures above grass canopy $\left({ }^{\circ} \mathrm{C}\right)$ in comparison to maize canopy when using regression analysis

\begin{tabular}{cccc}
\hline Grass - 2 m & Maize - ground & Maize - effective height & Maize - 2 m \\
\hline 5 & 4.0 & 4.2 & 4.6 \\
10 & 9.8 & 9.6 & 9.7 \\
15 & 15.6 & 15.0 & 14.7 \\
20 & 21.3 & 20.5 & 19.8 \\
25 & 27.1 & 25.9 & 24.8 \\
30 & 32.9 & 31.3 & 29.9 \\
\hline Determination coefficient & $\mathrm{R}^{2}=0.931$ & $\mathrm{R}^{2}=0.981$ & $\mathrm{R}^{2}=0.992$ \\
Linear regression & $\mathrm{y}=1.1526 \mathrm{x}-1.7295$ & $\mathrm{y}=1.0842 \mathrm{x}-1.2186$ & $\mathrm{y}=1.0086 \mathrm{x}-0.4117$ \\
\hline
\end{tabular}

at 2 meters) and the wheat, rape and maize canopies. The coefficient of determination $\left(\mathrm{R}^{2}\right)$ was calculated in order to establish the strength of the relationships.

When using the set of model temperatures in the wheat and rape canopies (Tab. I and Tab. II), it is obvious that at low air temperatures, the influence of warming the incompletely covered dark soil surface is considerably manifested, mainly during the radiation days. As a result, the air temperature at the ground levels of canopies is significantly impacted. The influence of this warm temperature flux was observed in wheat in the form of temperature increase by $1.6{ }^{\circ} \mathrm{C}\left(\mathrm{R}^{2}=0.93\right)$ and in rape by $1{ }^{\circ} \mathrm{C}$ $\left(\mathrm{R}^{2}=0.95\right)$ in comparison with the temperature at 2 meters above the grass canopy. $10^{\circ} \mathrm{C}$ appears to be the critical turning temperature at which the impact of the soil surface becomes less important. When the temperatures of the surrounding environment reached above $10{ }^{\circ} \mathrm{C}$, the canopies were colder at their ground levels due to the green shade effect (Kohli \& Saini, 2002). When using a model temperature, for example $20{ }^{\circ} \mathrm{C}$, the wheat canopy was colder by $2.9^{\circ} \mathrm{C}$ at the ground level and the rape canopy by $1.6^{\circ} \mathrm{C}$. This happens due to the fact that the closed canopy uses warmth for vapor in the form of latent vapor heat and simultaneously, it inhibits the insolation, and therefore, the daily temperature averages and courses are lower. With the rising ambient temperature, the effect of temperature suppression inside the canopies increases. Completely opposite results were measured in the maize canopy (Tab. III). At low temperatures of the surrounding environment $\left(5^{\circ} \mathrm{C}\right)$, the temperature at the ground level of the maize canopy was lower by
$1{ }^{\circ} \mathrm{C}$ and at higher temperatures of the surrounding environment (e. g. $20^{\circ} \mathrm{C}$ ), the temperature inside the maize canopy was higher by $1.3^{\circ} \mathrm{C}\left(\mathrm{R}^{2}=0.93\right)$. Similar results were achieved also by Středa et al. (2010). During the first part of the studied period, these fluctuations were influenced by the character of the bare soil surface of the unclosed maize canopy.

At the effective canopy height, the soil surface albedo does not have a significant impact (Krédl et al., 2010). Inside the wheat canopy, the temperature was lower at the effective height in comparison to all model temperatures. The coefficient of determination 0.94 indicates with a high probability that the wheat canopy temperature at the effective height was $4.7^{\circ} \mathrm{C}$ at the ambient temperature of $5^{\circ} \mathrm{C}$. At the model ambient temperature of $20^{\circ} \mathrm{C}$, there was a $94 \%$ perspective that the canopy temperature would be $19{ }^{\circ} \mathrm{C}$, which represents a significant difference of $1^{\circ} \mathrm{C}$. The temperature decrease can be considered to be the result of distinct air stagnation and the impact of the bigger robustness of the herb level. According to Atzema (1993), temperatures inside the wheat canopies at different heights are very diverse in comparison to the surrounding environment. Similar results were achieved by Sentelhas et al. (1993) and Yan \& Zhang (2007). At the same time, Tompkins et al. (1993) present that a more densely sown wheat canopy has a lower temperature by up to $1.5{ }^{\circ} \mathrm{C}$ during daytime. Even small air temperature differences can create changes in the epidemics of Septoria, Blumeria and Puccinia pathogens (Chelle et al., 2009). At the effective height of the rape canopy, the character of the above the ground 
biomass impact on the microclimate was noticeable up to the temperature of $20^{\circ} \mathrm{C}$ at which the canopy was still able to effectively decrease its temperature. At temperatures above $20{ }^{\circ} \mathrm{C}$, overheating of canopies by around $0.5{ }^{\circ} \mathrm{C}$ as compared to the ambient temperature had occurred. The effect of the biomass robustness was also observed in the maize canopy in which a temperature drop of $0.8^{\circ} \mathrm{C}$ occurred when the temperature of the surrounding environment was low. On the other hand, the course of the regression indicates that at $20{ }^{\circ} \mathrm{C}$, the maize vegetation temperature at the effective height was $20.5^{\circ} \mathrm{C}$ at the determination coefficient of 0.98 .

Surprisingly good relationship was found when evaluating the tightness of the linear correlation between the air temperature at $2 \mathrm{~m}$

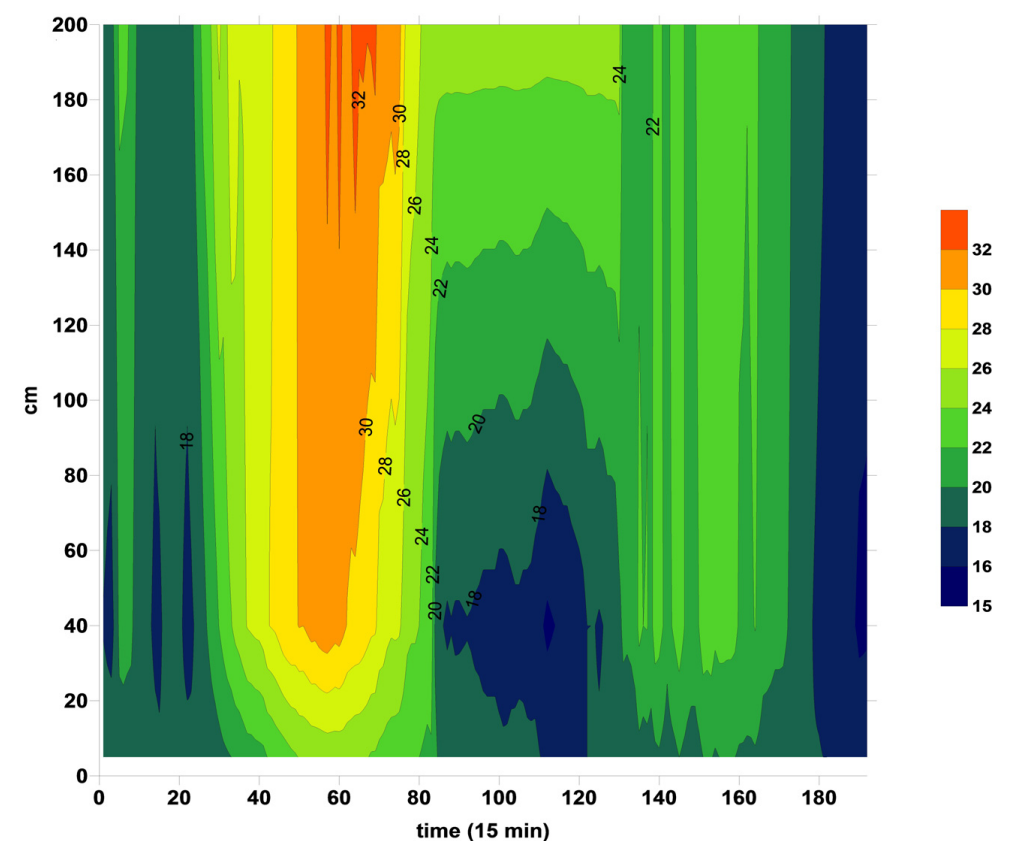

1: Isotherms of 15-minute air temperatures $\left({ }^{\circ} \mathrm{C}\right)$ in the vertical profile of wheat 12. 6. -13.6 .2010$

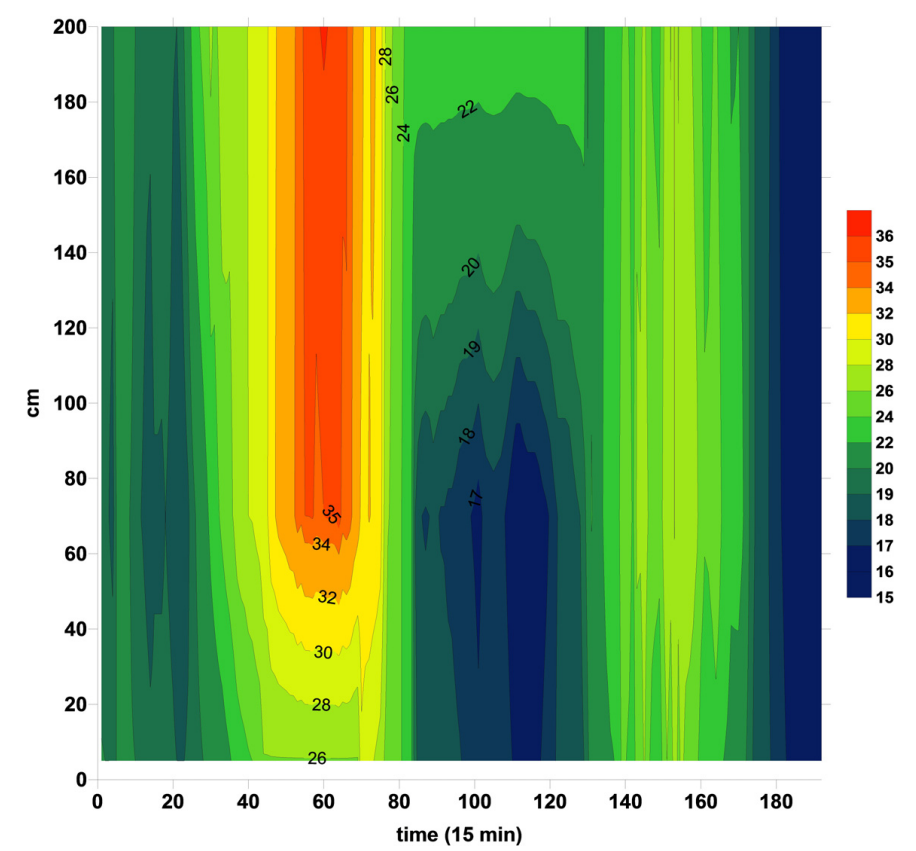

2: Isotherms of 15-minute air temperatures $\left({ }^{\circ} \mathrm{C}\right)$ in the vertical profile of rape 12. 6. -13.6 .2010$ 
above the grass canopy and the temperature at $2 \mathrm{~m}$ above the canopies of the studied crops. The air temperature above the wheat and maize canopies was not eminently influenced by the character and parameters of the canopies and did not differ from the temperatures of the surrounding envinronment $\left(R^{2}=0.98\right)$. Nevertheless, the character of the rape canopy was able to effect the air temperature above the canopy at both lower and higher temperatures, e. g. by $0.4^{\circ} \mathrm{C}$ when using the model temperatures of $5{ }^{\circ} \mathrm{C}$ and $20^{\circ} \mathrm{C}\left(\mathrm{R}^{2}=0.97\right)$. The temperature increase above the canopy can be understood as the increased reflectance of the canopy and the leaf area.

Air temperature stratification inside the wheat and rape canopies in the vertical profile during very

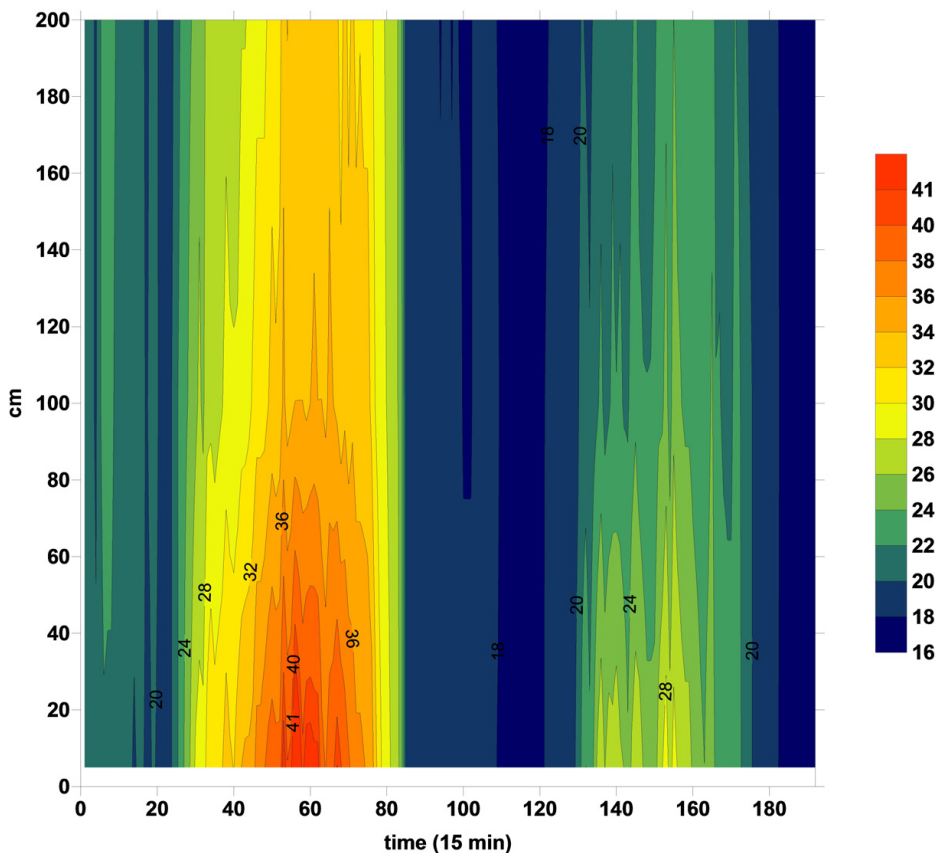

3: Isotherms of 15-minute air temperatures $\left({ }^{\circ} \mathrm{C}\right)$ in the vertical profile of maize 12. 6.-13.6.2010

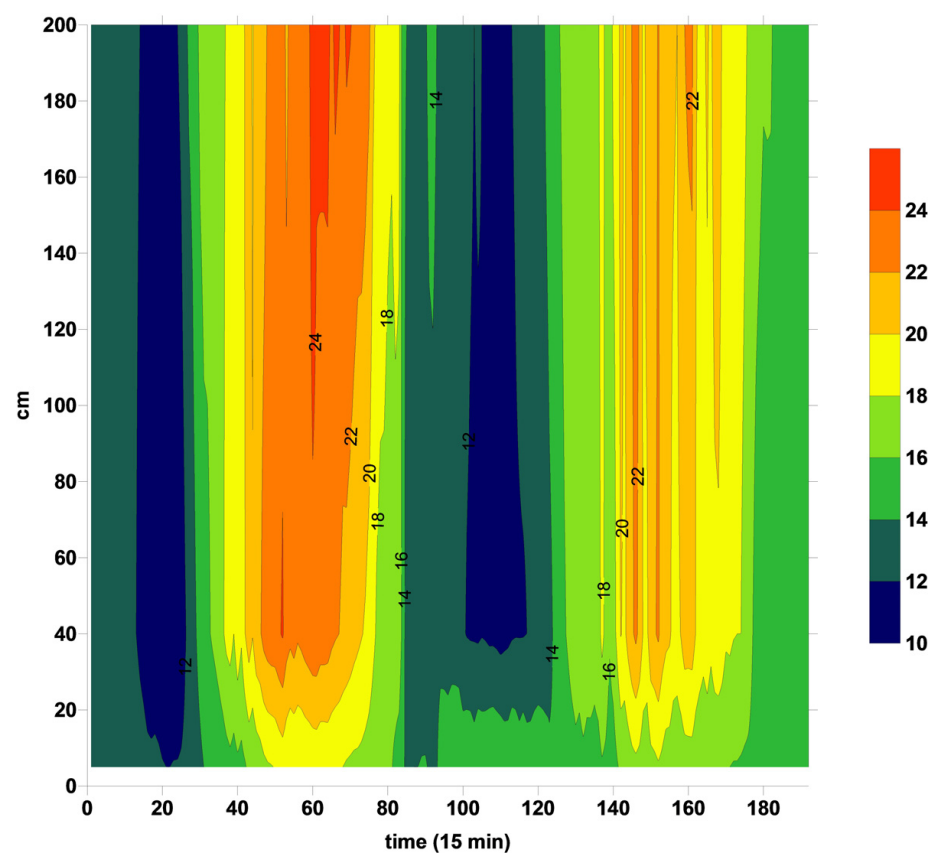

4: Isotherms of 15-minute air temperatures $\left({ }^{\circ} \mathrm{C}\right)$ in the vertical profile of wheat 28. 5.-29.5. 2010 
sunny days of June $12^{\text {th }}$ and $13^{\text {th }}$ can be seen in Fig. 1 and 2 . It is evident how the sun activity changed the temperature inside the canopies in the course of the day and how the canopies affected the microclimate. The differences between temperatures within the vertical canopy profile may be substantial during the time when the sun is positioned at the highest point above the horizon. In this particular case, the difference between the ground level and the effective height level was $6{ }^{\circ} \mathrm{C}$ in the wheat canopy and $9{ }^{\circ} \mathrm{C}$ in the rape canopy. During these days, the significant canopy effect was evident even in the course of the night hours when the temperatures at the ground and effective heights were significantly

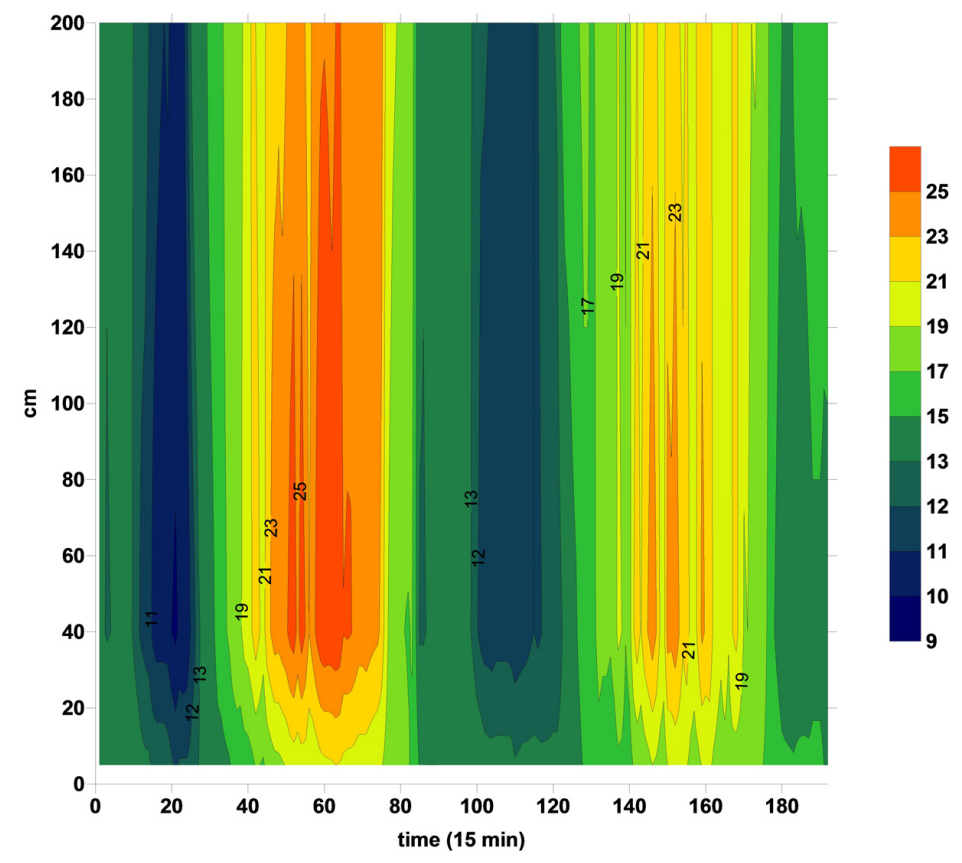

5: Isotherms of 15-minute air temperatures $\left({ }^{\circ} \mathrm{C}\right)$ in the vertical profile of rape 28. 5.-29. 5. 2010

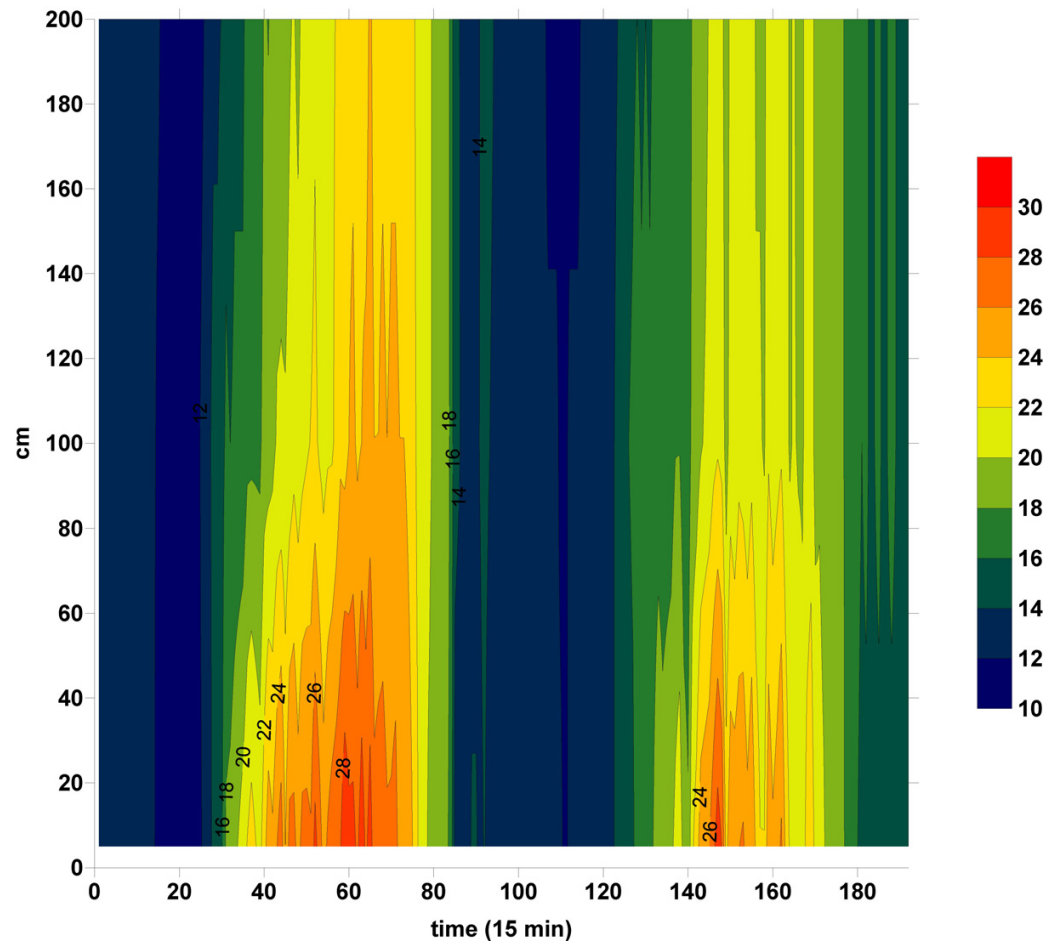

6: Isotherms of 15-minute air temperatures $\left({ }^{\circ} \mathrm{C}\right)$ in the vertical profile of maize 28. 5.-29. 5. 2010 
lower than the air temperature at 2 meters. Exactly opposite situation can be seen in the case of the maize canopy in Fig. 3. At the time of the highest sun activity, heating of the soil surface in the widely spaced maize canopy occurred and had lead to overheating of the ground canopy level. During these days, the temperature differences between the ground and effective canopy heights were $7{ }^{\circ} \mathrm{C}$. In the night hours, no temperature gradient difference within the canopy stratification was observed.

Days with distinctly diverse courses of temperatures during cloudy days of May $28^{\text {th }}$ and $29^{\text {th }}$ are displayed in Fig. 4 and 5. The above described conclusions apply in these cases, however, attention should be paid to the canopy's capacity to correct low air temperatures during night hours. Under these conditions, the air temperature at the ground levels was influenced by $2{ }^{\circ} \mathrm{C}$ in both wheat and rape canopies. In the case of the maize canopy, the temperature courses during these days were almost identical to the days of June $12^{\text {th }}$ and $13^{\text {th }}$ and at the same time it is evident that the air temperature during night hours was lacking distinct stratification (Fig. 6).

Relative air humidity values at the ground height of wheat and rape canopies were completely different from the air humidity values taken at the climatological station (Tab. IV a V). Lower values of determination coefficients indicate lower interpretation confidence of the canopy variable. Differences of the air humidity values inside the canopies and the values measured at the climatological station reached up to $60 \%$ in the case of wheat and $50 \%$ in rape. In contrast, the relative air humidity at the ground levels of the maize canopy was higher only by $9-3 \%$ (coefficient of determination - $0.80-$ Tab. VI.). The high level of conformity between humidity values of canopies and the values taken at the climatological station was affected by the absence of the maize canopy coverage during the first third of the studied period.

At the effective height, higher humidity values of wheat and rape canopies in comparison to the values taken at the climatologic station were observed. When ambient air humidity dropped to $30 \%$, the wheat canopy was able to sustain humidity of 53\%, when the surrounding environment's humidity was 70\%, the wheat canopy's humidity was higher only by $8 \%\left(R^{2}=0.85\right)$. In rape canopies, the differences at this height were at the level of $14 \%$ at the ambient humidity of $30 \%$, and only $4 \%$ at the ambient humidity of $70 \%\left(\mathrm{R}^{2}=0.84\right)$. Moreover, the results show that the wheat canopy has higher air humidity than the rape canopy. The air humidity at the effective height is influenced by the canopy's character and density. The canopy sustains higher air humidity by active photosynthesis and evapotranspiration. Completely opposite

IV: Monitored relative air humidity values above grass canopy (\%) in comparison to wheat canopy when using regression correlations

\begin{tabular}{|c|c|c|c|}
\hline Grass - 2 m & Wheat - ground & Wheat - effective height & Wheat - 2 m \\
\hline 30 & 70 & 53 & 43 \\
\hline 40 & 74 & 59 & 50 \\
\hline 60 & 82 & 72 & 65 \\
\hline 70 & 86 & 78 & 72 \\
\hline 90 & 93 & 91 & 86 \\
\hline 100 & 97 & 97 & 93 \\
\hline Determination coefficient & $\mathrm{R}^{2}=0.482$ & $\mathrm{R}^{2}=0.846$ & $\mathrm{R}^{2}=0.913$ \\
\hline Linear regression & $y=0.3831 x+58.746$ & $y=0.634 x+33.632$ & $y=0.7064 x+22.200$ \\
\hline
\end{tabular}

V: Monitored relative air humidity values above grass canopy (\%) in comparison to rape canopy when using regression correlations

\begin{tabular}{|c|c|c|c|}
\hline Grass - $2 \mathrm{~m}$ & Rape - ground & Rape - effective height & Rape-2m \\
\hline 30 & 61 & 44 & 40 \\
\hline 40 & 66 & 52 & 48 \\
\hline 60 & 79 & 67 & 63 \\
\hline 70 & 81 & 74 & 70 \\
\hline 90 & 91 & 89 & 85 \\
\hline 100 & 96 & 96 & 93 \\
\hline Determination coefficient & $\mathrm{R}^{2}=0.660$ & $\mathrm{R}^{2}=0.844$ & $\mathrm{R}^{2}=0.888$ \\
\hline Linear regression & $y=0.5057 x+45.685$ & $y=0.7408 x+22.210$ & $y=0.7443 x+18.100$ \\
\hline
\end{tabular}


VI: Monitored relative air humidity values above grass canopy (\%) in comparison to maize canopy when using regression correlations

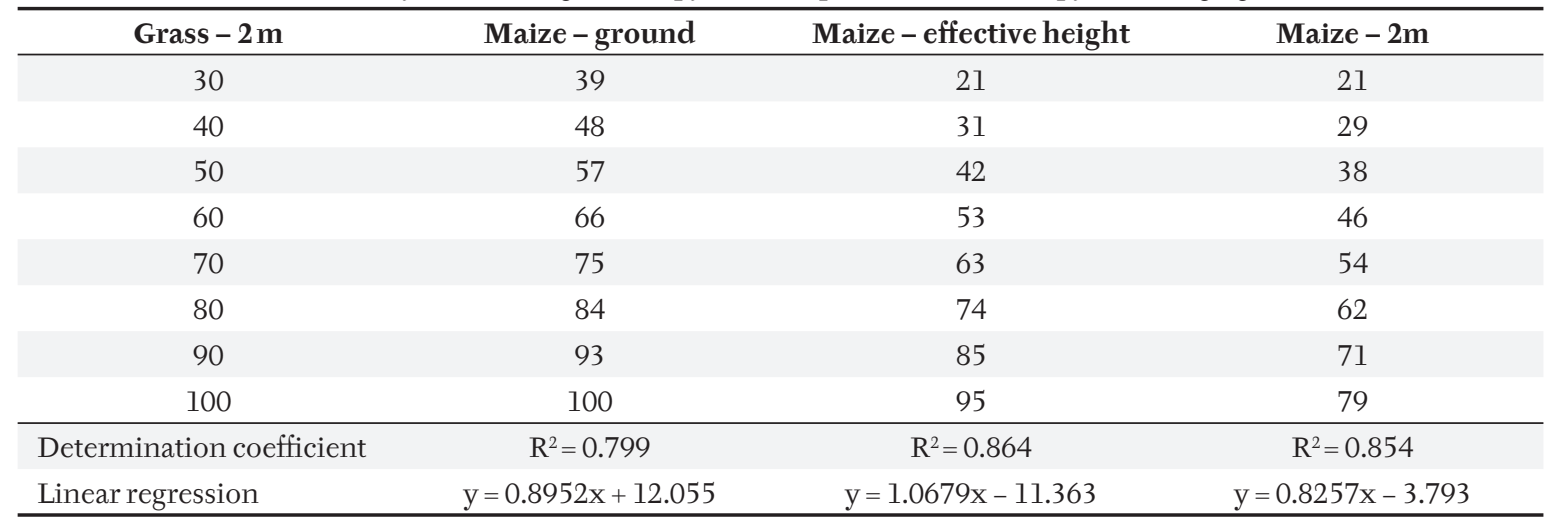

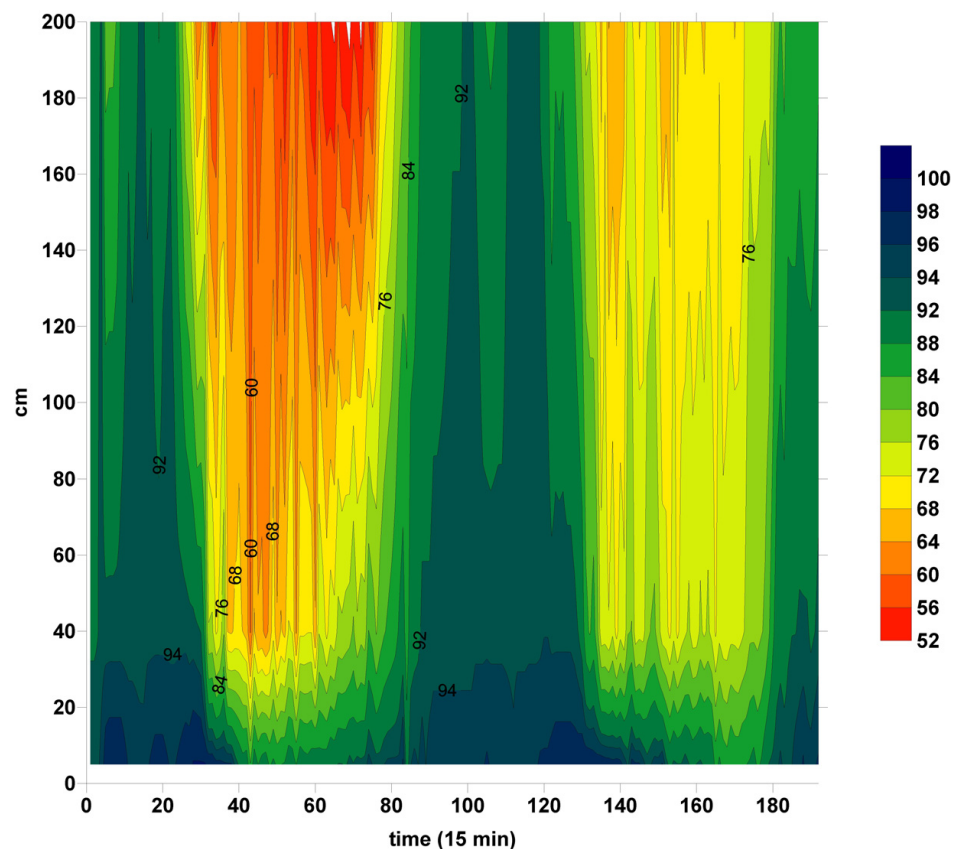

7: Isohumids of 15-minute air humidity values (\%) in the vertical profile of wheat canopy 12.6.-13.6. 2010

situation was found at the effective height of the maize canopy (Tab VI). The air humidity measured at the climatological station was higher by $9-5 \%$ (determination coefficient 0.86). It is due to the fact that at the beginning of its development, the maize canopy is not able to sustain air humidity from evaporation nor is it able to keep the air humidity produced by photosynthesis and transpiration.

Air humidity at 2 meters above the rape and wheat canopies was also higher in comparison to the standard climatological station. While the humidity at 2 meters above the grass canopy was $30 \%$, the wheat's humidity reached $43 \%$ and rape's humidity $40 \%$. The higher air humidity indicates that the canopy influences the microclimate of the adjoining atmosphere. With the rising humidity of the surrounding environment, the humidity of both canopies become equal and at 70\% there is no difference between the sites. The air humidity above the maize canopy was affected in the opposite way. In comparison to the air humidity above the grass canopy (30\% to $70 \%$ ), the humidity above the maize was lower by $9 \%$, respectively by $16 \%$ (coefficient of determination - 0.85). The higher humidity taken at the climatological station is conditioned by the impact of the grass vegetation that influences the air humidity by photosynthesis and transpiration. Up to the moment of complete canopy closure, the maize vegetation is not able to affect the microclimate inside the canopies and immediately above them.

The course of air humidity values in the vertical profile of wheat during very warm sunny days of June $12^{\text {th }}$ and $13^{\text {th }}$ is displayed in Fig. 7. The difference between humidity values at the ground level and the effective height was $25 \%$ during these days. For the rape canopy, the same days are presented in Fig. 8, the canopy sustained by $8 \%$ higher humidity at its effective height in comparison to the ground 
level during the light part of the days. At this time, the effect on the air humidity was caused by the higher canopy density at the effective height of the rape canopy. In contrast, the widely spaced maize canopy that was approximately $40 \mathrm{~cm}$ tall was not able to influence the air humidity at different parts of its vertical profile (Fig. 9). Due to the high level of underground water and previous persistent precipitation, the water was not soaked into the soil and was left on the soil surface of the maize canopy. This impacted the relative air humidity mainly in the dark part of the day when the relative humidity had reached almost 100\% up to the height of $120 \mathrm{~cm}$ above the soil surface.

Very similar results were found when comparing radiation days of May $28^{\text {th }}$ and $29^{\text {th }}$ (Fig. 10 and 11).

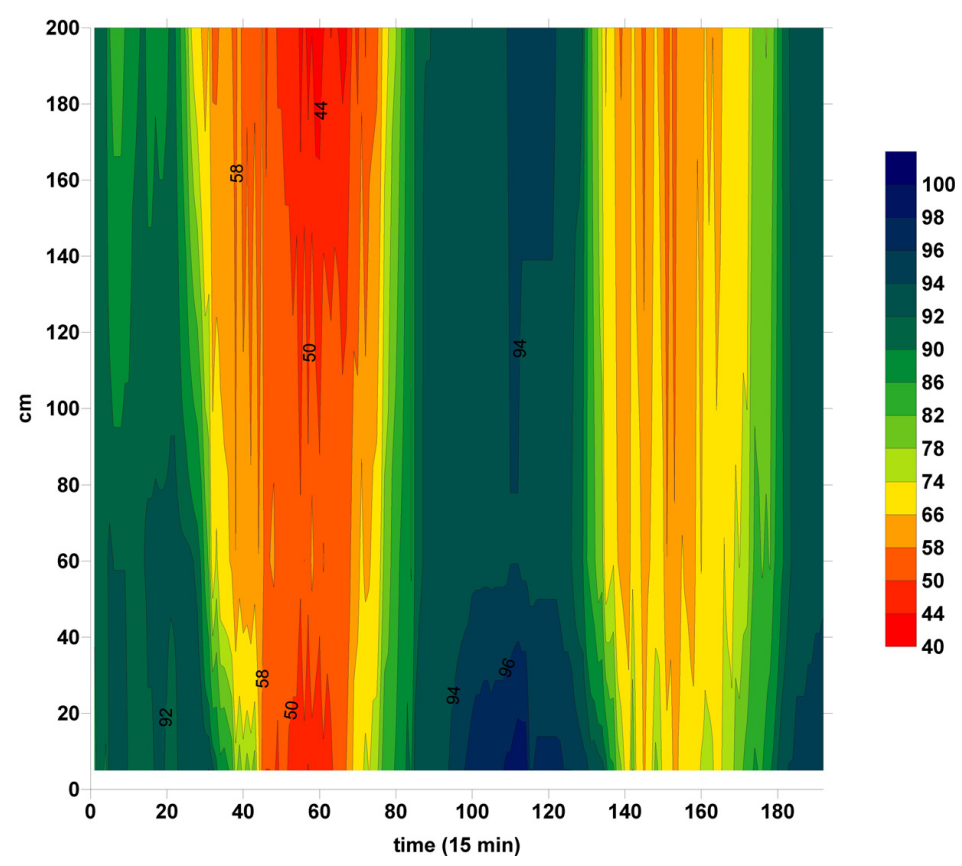

8: Isohumids of 15-minute air humidity values (\%) in the vertical profile of rape canopy 12. 6. -13.6 .2010$

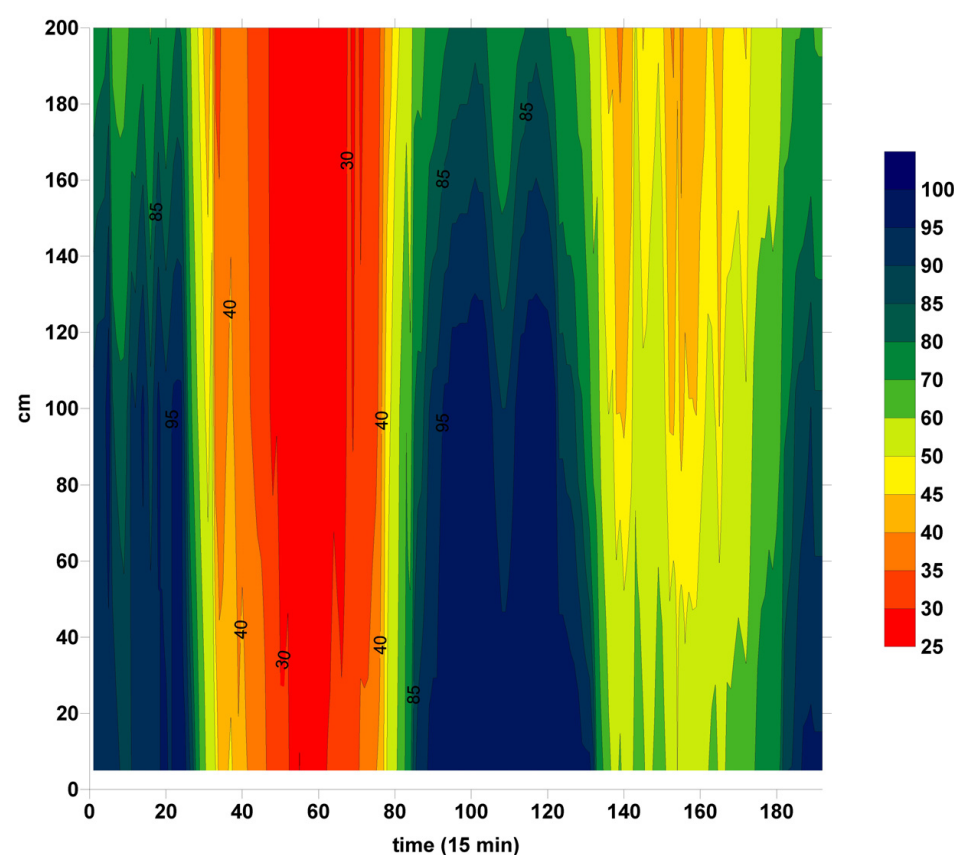

9: Isohumids of 15-minute air humidity values (\%) in the vertical profile of maize canopy 12. 6.-13.6. 2010 
During the light part of the day, air humidity in the wheat and rape canopies corresponds to the difference of $20 \%$ between the ground and the effective height. During the dark part of the day, the higher air temperature affects the air humidity that is higher by $10 \%$ at the ground level in the case of wheat and by $2 \%$ in the case of rape. The air humidity in the maize canopy during the light and dark parts of the days was significantly affected by the water trapped on the soil surface (Fig. 12).

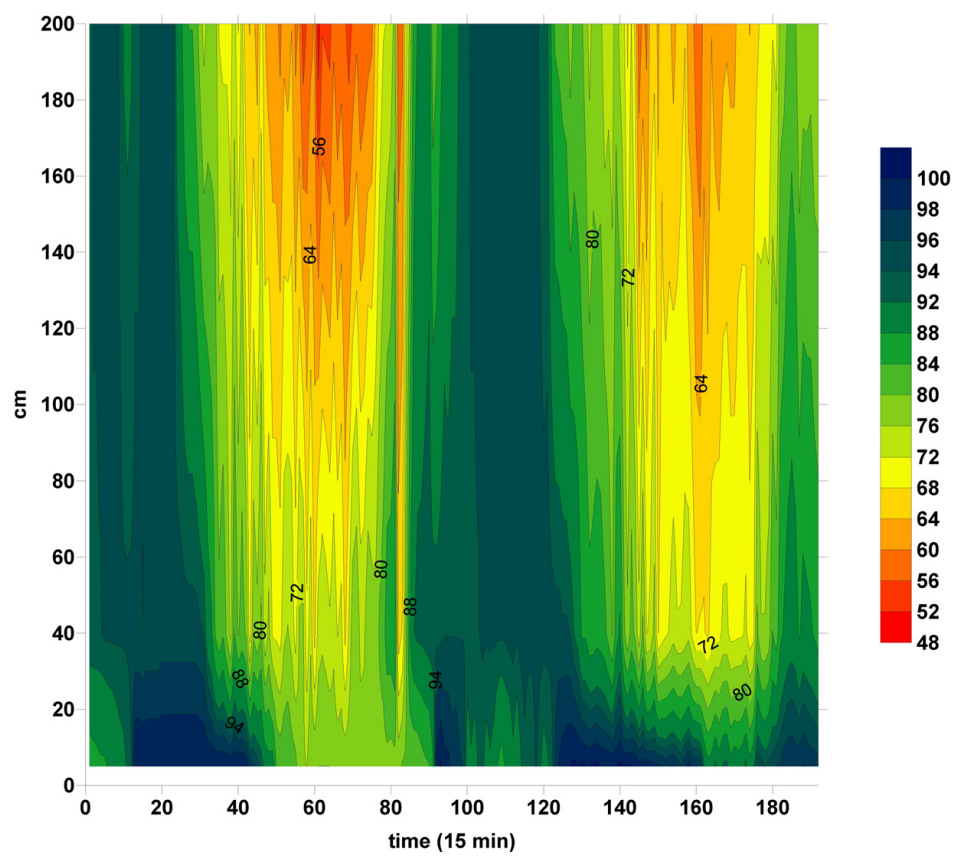

10: Isohumids of 15-minute air humidity values (\%) in the vertical profile of wheat canopy 28.5.-29.5. 2010

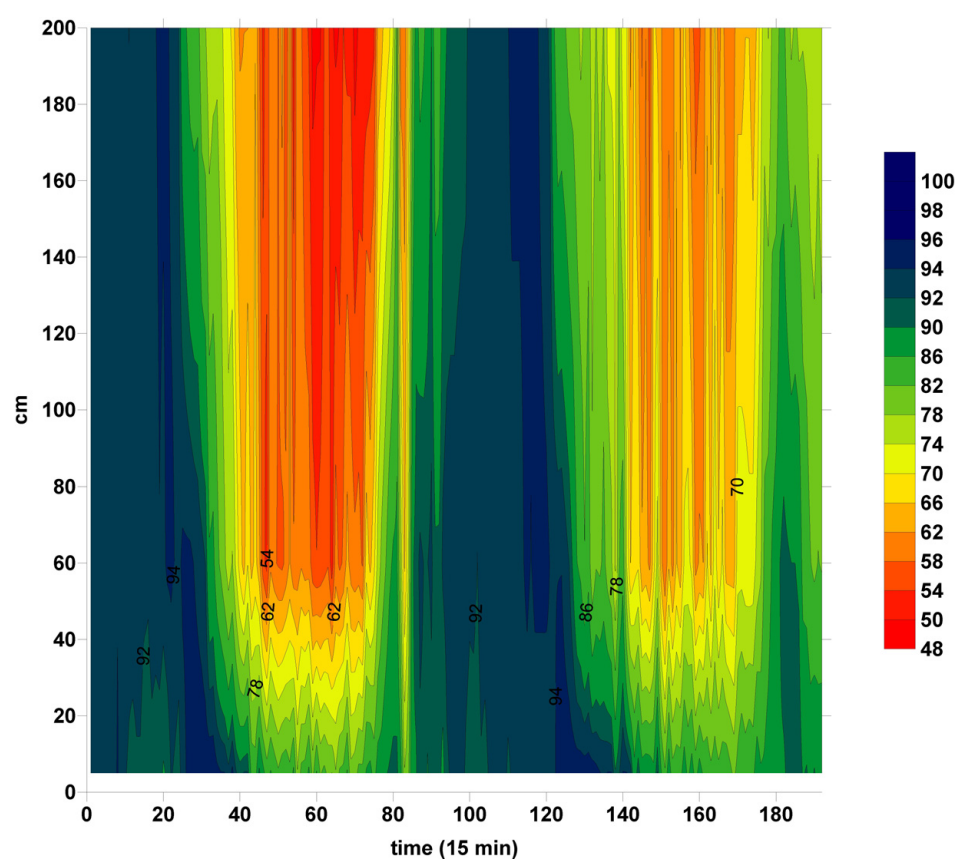

11: Isohumids of 15-minute air humidity values (\%) in the vertical profile of rape canopy 28. 5.-29.5. 2010 


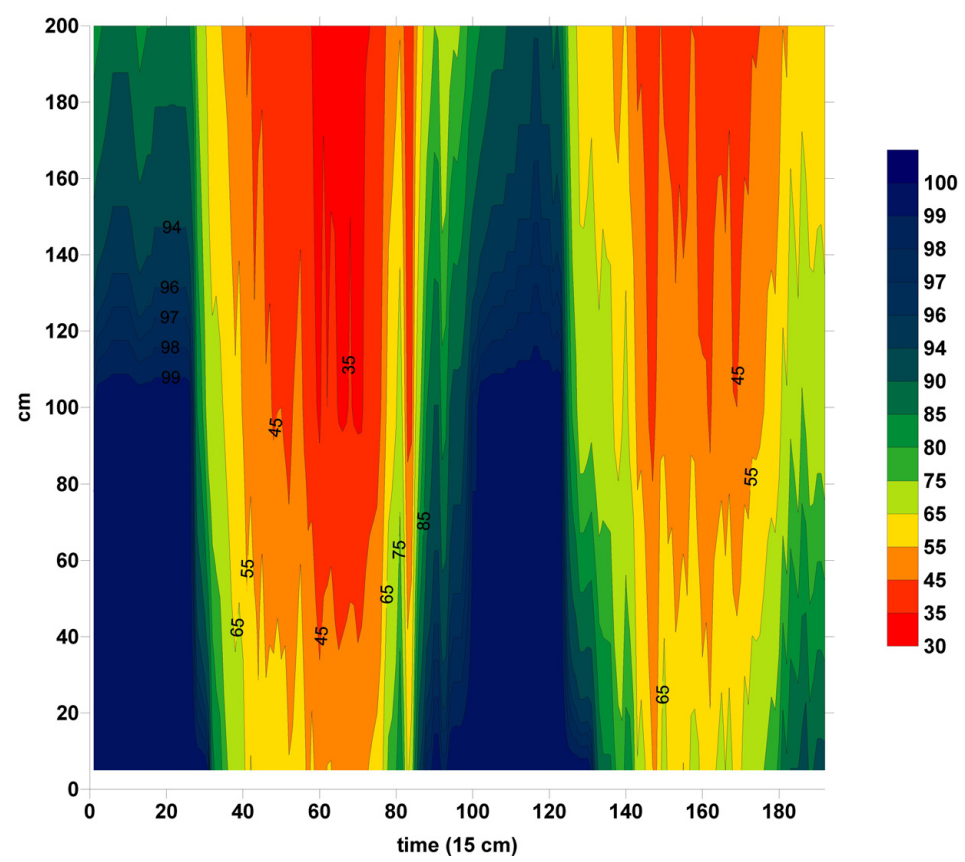

12: Isohumids of 15-minute air humidity values (\%) in the vertical profile of maize canopy 28.5.-29.5. 2010

\section{SUMMARY}

The differences of air temperature and relative air humidity in wheat, rape and maize canopies at three heights (ground level, effective canopy height and 2 meters above the soil surface), and their comparison with the temperature values of the nearest standard climatological station at the height of 2 meters were studied. The average hourly air temperature and humidity intervals were statistically processed by the linear regression analysis in order to predict the values of canopies' temperature and humidity in dependence on the surrounding temperature and humidity. Simultaneously, the air temperature and humidity values were displayed by the means of the isotherms and isolines of humidity values. The results show that the wheat, rape and maize canopies have microclimates that are rather different from those of their surrounding environments. The temperature at the ground levels of rape and wheat canopies were by 1 to $1.6^{\circ} \mathrm{C}$ higher when the surrounding environment's temperature was $5^{\circ} \mathrm{C}$. When the surrounding temperature ranged between 15 to $30^{\circ} \mathrm{C}$, these canopies were colder by 0.8 to $6^{\circ} \mathrm{C}$. At the effective height of the wheat canopy, it was colder by 0.8 to $1.5^{\circ} \mathrm{C}$ when compared to the surrounding environment's temperature ( 15 to $30^{\circ} \mathrm{C}$ ). On the other hand, when the surrounding environment's temperature was higher, overheating by up to $0.6{ }^{\circ} \mathrm{C}$ of the rape canopy occurred. Maize canopies had diverse air temperature values during the studied period. The ground level was colder by $1{ }^{\circ} \mathrm{C}$ (the temperature of the environment was $5^{\circ} \mathrm{C}$ ) and at $30^{\circ} \mathrm{C}$, the canopy was warmer by $2.9^{\circ} \mathrm{C}$. A similar tendency was also found at the effective height. At the same time, diverse humidity values within the whole vertical profile of the wheat and rape canopies were found. The differences between humidity values (in comparison to the environment) reached up to $40 \%$. However, maize canopies had lower air humidity by up to $9 \%$ at the effective height.

\section{Acknowledgements}

This paper was realized thanks to the contribution by the grant IGA No. IP 11/2010 AF of the Mendel University in Brno and with the support of the Research plan No. MSM6215648905 „Biological and technological aspects of sustainability of controlled ecosystems and their adaptability to climate change" granted by the Czech Ministry of Education, Youth and Sport. 


\section{REFERENCES}

ATZEMA, A., J., 1993: Moisture content of cereals at harvesting time by comparing microclimate values and standard weather data. Neth. J. Agr. Sci. 41, 3: 167-178.

GEIGER, R., 1965: The climate near the ground. Cambridge: Harvard University Press. Sth edition, 611 s. ISBN 10: 0674135008

HALLAIRE, M., RAPILLY, F., PAUVERT, P., 1969: Effets de l'irrigation sous ses différents modes sur la biologie, l'étiologie et l'épidémiologie des maladies des plantes. Ann. Phytopatho., 1: 9-29.

HENZE, M., BEYER, M., KLINK, H., VERREET, J., A., 2007: Characterizing meteorological scenarios favorable for Septoria tritici infections in wheat and estimation of latent periods. Plant Dis., 91, 11: 1445-1449.

CHELLE, M., LIU S., NEY B., 2009: Which air temperature drives epidemiological processes of fungl folia wheat diseases at leaf scale? AFPP-9ème Conférenceinternationale sur les maladies des plantes tours - 8 et 9 décembre 2009.

CHEN, J., SAUNDERS, S., C., CROW, T., R., NAIMAN, R., J., BROSOFSKE, K., D., MROZ, G., D., BROOKSHIRE, B., L., FRANKLIN, J., F., 1999: Microclimate in forest ecosystem and landscape ecology. Bioscience, 49: 288-297.

CHUNGU, C., GILBERT, J., TOWNLEY-SMITH, F., 2001: Septoria tritici blotch development as affected by temperature, duration of leaf wetness, inoculum concentration, and host. Plant Dis., 85, 4: 430-435.

KOHLI, A., SAINI, B., C., 2002: An evaluation of crop canopy temperatures for late sown wheat in an agroforestry system. Geobios (Jodhpur), 29, 2.-3. April-July: 170-174.

KRÉDL, Z., STŘEDA, T., KMOCH, M., POKORNÝ, R., 2010: Mikroklima v porostech pšenice a řepky. In: Úroda, Vědecká př́loha "Aktuální poznatky v pěstování, šlechtèní, ochraně rostlin a zpracování produktů". Referáty z konference ze dne 11.-12. 11. 2010 v Brně. VÚP a Zemědělský výzkum Troubsko. [CD-ROM]. 717-720.

KURPELOVÁ, M., COUFAL, L., ČULÍK, J., 1975: Agroklimaticképodmienky ČSSR. Hydrometeorologický ústav: Bratislava, $270 \mathrm{~s}$.

LOVELL, D. J., HUNTER, T., POWERS, S. J., PARKER, S. R., BOSCH, F., 2004: Effect of temperature on latent period of septoria leaf blotch on winter wheat under outdoor conditions. Plant Pathol., 53, 2: 170-181.

SENTELHAS, P. C., PEDRO, J. M. J., FELICIO, J. C., 1993: Effects of different conditions of irrigation and crop density in microclimate and spot blotch and powdery mildew occurrence. Bragantia, 52, 1: 45-52.

STŘEDA, T., HAJZLER, M., BROTAN, J., ROŽNOVSKÝ, J., 2010: Teplotní zvrstvení v porostu kukuřice. In: Bioklima 2010. Sborník príspèvkü z mezinárodní konference. 1. vyd. Praha: ČZU v Praze, 423-429. ISBN 978-80-213-2097-0.

TOMPKINS, D. K., FOWLER, D. B., WRIGHT, A. T., 1993: Influence of agronomic practices on canopy microclimate and septoria development in no-till winter wheat produced in the Parkland region of Saskatchewan. Can. J. Plant Sci., 73, 1:331-344.

VANWALLEGHEM, T., MEENTEMEYER, R. K., 2009: Predicting Forest Microclimate in Heterogeneous Landscapes. Ecosystems, 12: 1158-1172.

YAN, J. F., ZHANG, S. W., 2007: Study on the heat balance and the meteorological effect during milk-filling and burliness stage of the different type wheat. Journal of Northwest A \& F. University Natural Science Edition, 35, 9: 49-52, 57.

Address

Ing. Zdeněk Krédl, Ústav pěstování, šlechtění rostlin a rostlinolékařství, Mendelova univerzita v Brně, Zemědělská 1, 61300 Brno, Česká republika, e-mail: kredl.zdenek@centrum.cz 